The Third Pole: Journal of Geography

Vol. 17: 73-82, 2017

Department of Geography Education, Central Department Education, T.U., Kathmandu, Nepal

\title{
FEMALE OWNERSHIP OF FIXED ASSETS IN NEPAL: A REGIONAL PERSPECTIVE
}

\author{
Shiba Prasad Rijal ${ }^{1}$
}

\begin{abstract}
Fixed assets especially house and land have significant importance in wealth, social security and power in Nepal. Ownership over these assets has greater implications in women's status within households and communities. This also decides the economic dependence or independence and provides the means to be engaged in productive economic activity. The present study aims at analyzing the regional pattern of female ownership of fixed assets- house and land. Relevant data were acquired from a desk review of published and unpublished literature including online database. The study finds that there is a great gender discrepancy in ownership of fixed assets in Nepal and this varies across ecological zones and provinces. Female ownership of both land and house is associated with 10.7 percent while only 9.0 percent have ownership of land only. Tarai shows relatively positive condition as compared to other ecological zones with female ownership of 12.3 percent households with house and land and 10.5 percent with only land. Among provinces, the most negative situation exists in the province six as compared to others. The socio-cultural barriers are still a major challenge for women's ownership of property in Nepal.
\end{abstract}

Keywords: Economic dependence, ecological zones, fixed assets, inequality, ownership, parental property, province.

\section{Introduction}

Gender equality matters as a fundamental human right and for development (Cerise \& Francavilla, 2012). Nepal exhibits a wide gender-gap in both social and economic dimensions (Mahat, 2003) despite several progressive steps taken by the government and

1 Dr. Rijal is an Associate Professor of Geography Education, Central Department of Education, T.U. Kirtipur, Email: rijalshibaprasad@gmail.com 
non-governmental agencies towards gender equality throughout the past few decades. During the course, Nepal government has ratified a number of international commitments to nondiscrimination, gender equality, and social justice after restoration of democracy in 1990. The constitution promulgated in 1991 guaranteed nondiscrimination against on the basis of sex and a number of legal reforms were made to eliminate genderbased discrimination. As a result, several discriminatory provisions were eliminated and entitled women to significant rights including inheritance of property (IOM, 2016). With these government interventions and changes in political circumstances, the situations of women have positively changed to some extent over the period of time (Acharya, 2014; IOM, 20016; ADB, 2016); however, there remains a significant gap in gender equality. Still, the status of Nepalese women lags far behind that of men- low levels of access to education, economic, social, and political opportunities and they are socially excluded. Among others, discriminatory social institutions, social norms, and practices are the main hindering factors in restricting women's access to opportunities, resources and power (Basnet, 2013). Gender discrimination and social exclusion in Nepal starts right after the birth and it continues throughout the life cycle in different forms (Pokhrel, 2008) and entrenched in the political, economic, and social fabric of Nepal (ADB, 2010).

Gender discrimination exists in various aspects (Acharya, 2014) including property ownership. FAO (2011) claimed that strengthening woman's access to and control over fixed asset is an important means of raising women's status and influence within households and communities. Access to and control over these assets is synonymous with wealth, status and power (IOM, 2016), and also provides them with a sense of economic security and bargaining strength in economic transactions (Agrawal, 1994). Further, the ownership of assets provides the means to be engaged in productive economic activity as person without ownership of fixed assets cannot get loan from the banks that hinders to engage him or her for self employment and severely restricted in pursuit of activity of his/her choice.

The inequality in access and control in property is overwhelming and straddles continents and cultural contexts. Despite cultural diversity and differences, land is inherited universally in all communities from father to son (UNFPA,2007). The situation in Nepal is not much different. Father's property especially house and land are generally inherited by the sons and daughters are much less likely to inherit these. Even with the recent amendment of civil code (IOM, 2016), the patriarchal cultural norms and tradition continue to hinder women's access to and control over such properties. Still, a large section of female in Nepal does not have access to these properties. As of population census 2011, women enjoy ownership over land and other property is only 19.7 percent of households in Nepal (CARE, 2015; IOM, 2016) while it was only 10.8 
percent in 2001 (IOM, 2016). The situation regarding female ownership of these assets is not uniform throughout the country and varies significantly by ecological zones and provinces. In this context, present study is focused in analyzing the regional pattern on female ownership of fixed assets especially of house and land.

\section{Study Methods and Site Characteristics}

\section{Study methods}

Many researches on disparities in asset ownership are carried out at the level of the household and this unit of analysis is in many instances practical and appropriate (Antonopoulos \& Floro, 2005). The descriptive cum analytical this study is based on secondary data acquired from a desk review of published and unpublished literature including online database. Household level statistics related to female ownership of fixed assets were acquired from population and housing census reports of Central Bureau of Statistics (CBS) Nepal 2011. Since, the scope of this study is limited in analyzing female ownership pattern of fixed assets considering only two variables of fixed assets i.e. ownership of house and land, and land only without considering whether these assets were inherited or marketed as census report does not provide these details. The ecological level data were acquired directly from population and housing census 2011 while province level data were acquired by calculating district level data from the same source. Relevant other data/information was narrated from varieties of published and unpublished sources.

\section{Characteristics of study site}

Since the study is focused in analyzing regional scenarios on female ownership of fixed assets highlighting the case of ecological zones and provinces of Nepal, this section provides brief regional characteristics of Nepal. Nepal covers an area of 147,181 square kilometer with physical and socio-cultural diversity by ecological zones and provinces. Ecologically, the country is divided into three distinct east-west or longitudinal geographical regions: Mountain region stands in the northern part, a central Hilly region and Tarai in the southern part. As of population census 2011, Nepal provides home for 26.6 million populations (CBS, 2012) with uneven distribution spatially. The Mountain zone with almost 35 percent of the total area represents about 6.7 percent of the total population. The Hill with 44 percent of the total area contains 43.0 percent of the population. Likewise, the Tarai plain with 21 percent of the area is associated with 50.3 percent of the total population (CBS, 2012). Nepal is inhabited by people of different ethnic and cultural origins as census 2011 has recorded 125 castes and ethnic groups in 
Nepal. Tarai area is inhabited mostly by people of Tarai caste/ethnic groups while in the Hills and Mountain people are of mostly other than Tarai caste and ethnic groups. Thus, socio-cultural diversity is a common feature of ecological zones. Female outnumber the male population in all ecological zones.

Likewise, administratively, the country is divided into 7 provinces (Figure 1). The extension of provinces is mostly north-south considering ecological zones except province two. Province two is almost entirely situated in the Tarai ecological zone with east-west extension. Provinces 1, 3 and 7 extend in all ecological zones. Province five extends in both Tarai and hill zones while province six extends in hill and mountain zones. There is wide variation in provinces in terms of areal size and population concentration. Province two is the smallest one in terms of area (6.6 percent) with highest population density (559 persons per square $\mathrm{km}$ ) while province six is the biggest in terms of areal size (about 21 percent) with lowest population density i.e. 50 persons per square $\mathrm{km}$. As in ecological zones, female population outnumber in all provinces except province two.

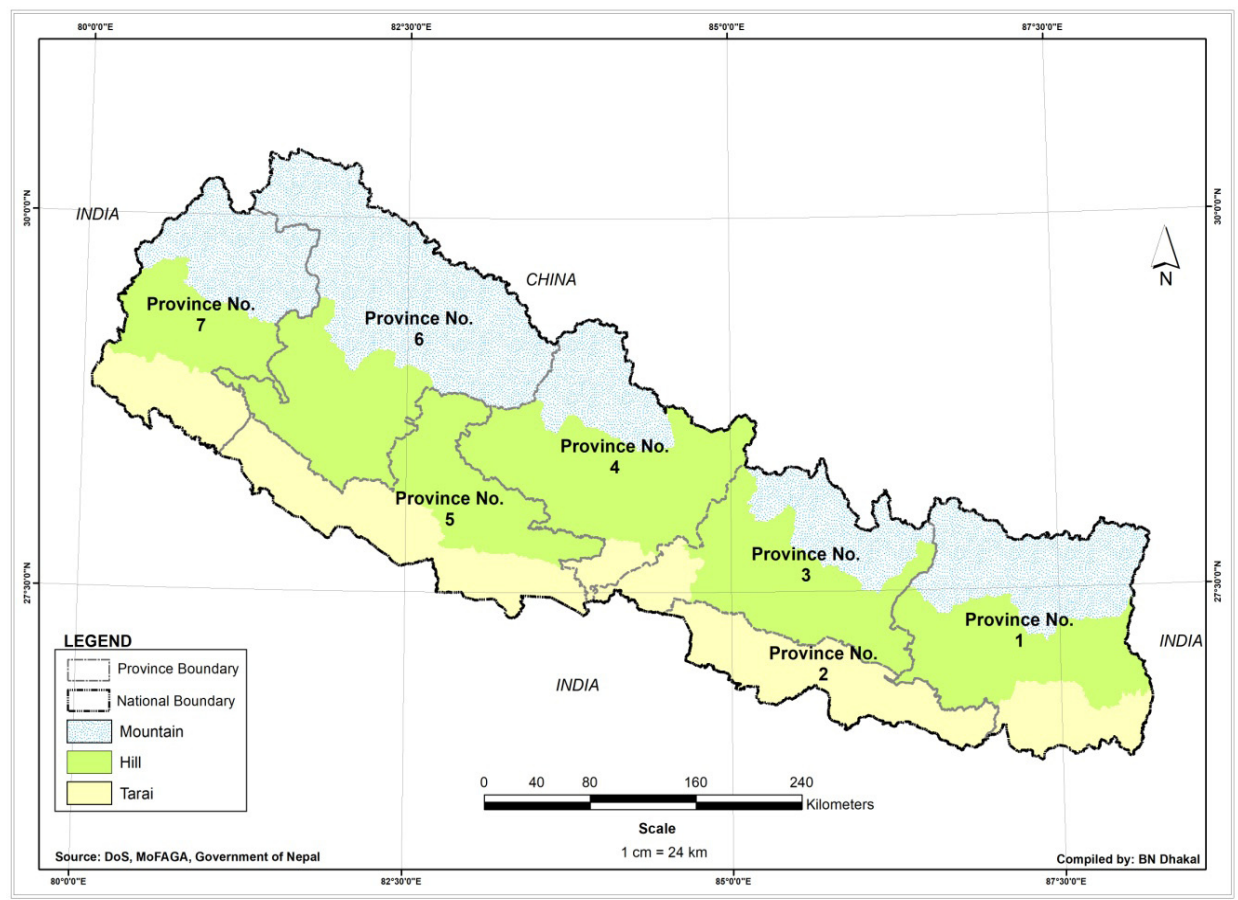

Figure 1: Ecological Zones and Provinces in Nepal 
Nepal is one of the poorest countries of the world, the population living below poverty line accounted for 23.8 percent (GoN, 2015) and the per-capita income (PPP) was US\$ 1160 in 2014 (GoN \& UNDP, 2014). There is wide variation in Human Development among ecological zones. In respect to Human Development Index (HDI), the Hills have the highest value (0.520), compared to the Tarai (0.468) and the Mountains (0.440). Likewise, the Human Poverty Index (HPI) for Mountain, Hill and Tarai was 38.51, 29.20 and 33.04 respectively. Similarly, the Gender Development Index (GDI) value is the highest for the Hills at 0.515 , followed by the Tarai at 0.458 and the Mountains at 0.430. A large section of female population belongs to illiterate condition in Nepal. Of the total female population aged 5 years and above, 50 percent still belongs to illiterate category as against only 25 percent illiterate male population (Shrestha \& Rijal, 2016). The literacy status of women is comparatively lower in all ecological zones and provinces.

\section{Importance of Asset Ownership}

Among others, land and housing are the most valued assets which have significance importance in people's lives and livelihoods. Access to and control over these assets provide multiple benefits to individuals and households in wealth, social status and power (World Bank, 2008; FAO, 2011; IMO, 2016) including reducing poverty, cushioning risk and vulnerability from natural disasters, illness, or financial crises. Many studies showed the importance of assets ownership (Agarwal, 1994, Doss, Grown \& Deere, 2008; Njuki, \& Mburu, 2013; Shrestha and Rijal, 2016). Asset ownership is often highly correlated with economic growth, poverty reduction and with a reduction to vulnerability and risk at the household level. Ownership over the asset can play a significant role in combating gender discrimination by enhancing the bargaining power of women (Mishra \& Sam, 2016).

Njuki \& Mburu (2013), based on observation from some African nations, conclude that ownership of assets is critical for increasing agricultural productivity. They also claimed that putting assets in the hands of women increases their bargaining power, their role in household decision-making and household spending on children's education and health. The observation of Doss, Grown \& Deere (2008) is also similar. They stated that ownership and control over assets such as land and housing provide direct and indirect benefits to individuals and households, including a secure place to live, the means of a livelihood protection during emergencies, and collateral for credit that can be used for investment or consumption. Likewise, In Colombia women use property and social 
assets to negotiate for the right to work, control their own income, move freely, and live without spousal violence (Cited in Doss, Grown \& Deere, 2008). The studies from South Asia also showed the greater importance of assets ownership. They claimed that women who owned land had greater say in household decision-making than women without land (Pokharel, 2008; Doss, Grown, \& Deere, 2008). IOM (2016) also stated that in Nepal land ownership has the potential to enhance women's social status, livelihood options and psychological well-being and also enhances enjoyment of a broad range of rights for women (OHCHR \& UN Women, 2013). Ownership is also a social status and provides female with a sense of economic security (Pokheral. 2008) and bargaining strength in economic transactions (Agrawal, 1994). Ownership also helps an individual to become an independent in the society. These facts clearly indicate greater importance of assets ownership in many respects. However, women's ownership of property does not always imply that they have ultimate control of these assets. Women may own these assets through the market or inheritance may not have decision making authority over such assets (Njuki, \& Mburu, 2013).

\section{Female Ownership of Fixed Assets}

Land and housing are valuable assets for women that enhance their social and economic status, and secure livelihoods. In the past, women had been denied access to and control over familial property (ADB, 2010). As a result, there was a great gender discrepancy regarding ownership of familial property especially of house and land. However, in recent years, with number of positive steps taken by the government with legal reforms and amendments of new civil codes, the situation of women has changed. Women's ownership of fixed assets increased to about 20 percent (Table 1) from 10.8 percent in 2001 (IOM, 2016) within a decade. This indicates little progress; however, women are still far behind regarding access to land ownership. Though not clear, there are some reasons for this positive change. First, the positive implications of constitutional and legal reforms that government has taken regarding equal right of parental property to unmarried daughters and sons along with increased female awareness. Second, discount in land registration fees provided by the government to female. In recent years, there is an increasing tendency of land registration in female's name in both rural and urban areas considering low land registration fees to pay by female. The third reason is dowry that women receive land and house from their parents. 
Shiba Prasad Rijal / Female Ownership of Fixed Assets in Nepal: A Regional Perspective

Table 1: Households with female ownership of fixed assets in Nepal

\begin{tabular}{lll}
\hline Asset types & Number & Percent \\
\hline House \& Land & 580757 & 10.7 \\
Land only & 488314 & 9.0 \\
Neither house nor land & 4310560 & 79.5 \\
Not stated & 43666 & 0.8 \\
\hline Total & 5423297 & 100.0 \\
\hline
\end{tabular}

Source: Calculated from CBS, 2012

Female ownership of both land and house is associated with 10.7 percent (Table 1). Likewise, land ownership of land only is associated 9.0 percent of the households. Significantly large proportion of households (79.5 percent) in Nepal is without female ownership of fixed assets. They own neither house nor lands. This indicates a weak economic condition of the female and more dependent on their male family members. And it is quite evident that female discrimination in ownership of fixed assets continues to be prominent phenomenon in the country.

\section{Female Ownership of Fixed Assets by Ecological Zones}

Gender discrepancy on ownership of fixed assets varies across ecological zones (Table 2). The Tarai shows relatively positive condition as compared to other ecological zones (Mountains and Hills) with female ownership of 12.3 percent households with house and land and 10.5 percent with only land. In both respects, the Tarai ranks above the national average. Slightly better conditions are found in the Hills with female ownership of about 10.0 percent and 8.0 percent respectively as compared to the Mountains. The Mountain falls far below the national average in both cases.

Table 2: Households by female ownership of fixed assets by ecological zone (\%)

\begin{tabular}{lllll}
\hline Ecological Zones & House \& land & Land only & $\begin{array}{l}\text { Neither house } \\
\text { nor land }\end{array}$ & Not stated \\
\hline Mountain & 5.5 & 5.6 & 88.4 & 0.6 \\
Hill & 9.9 & 8.0 & 81.4 & 0.7 \\
Tarai & 12.3 & 10.5 & 76.3 & 1.0 \\
\hline Nepal & 10.7 & 9.0 & 79.5 & 0.8 \\
\hline
\end{tabular}

Source: Calculated from CBS, 2012 
More than 88 percent households are without female ownership of fixed assets in the Mountain zone. Female ownership of both land and house is less than six percent in this ecological zone.

\section{Female Ownership of Fixed Assets by Province}

There is also greater gender discrepancy on ownership of fixed assets by province. The most negative situation exists in the province six as compared to others. In this province only 4.5 percent of the household has female ownership of both house and land (Table 3). Likewise, the situation of province seven is not much positive; in this province only 4.8 percent household has female ownership of house and land. Among provinces, highest performance on ownership of fixed assets (house and land) is found in province one with 13.8 percent of households having female ownership of house and land.

Table 3: Households by female ownership of fixed assets by province (\%)

\begin{tabular}{lcccc}
\hline Province & House \& Land & Land only & $\begin{array}{c}\text { Neither house nor } \\
\text { land }\end{array}$ & Not stated \\
\hline 1 & 13.8 & 12.6 & 72.9 & 0.6 \\
2 & 9.3 & 10.8 & 78.4 & 1.5 \\
3 & 11.8 & 8.8 & 78.6 & 0.8 \\
4 & 12.3 & 8.9 & 78.1 & 0.7 \\
5 & 11.3 & 8.3 & 79.8 & 0.6 \\
6 & 4.5 & 3.4 & 91.4 & 0.6 \\
7 & 4.8 & 3.1 & 91.6 & 0.5 \\
\hline Total & 10.7 & 9.0 & 79.5 & 0.8 \\
\hline
\end{tabular}

Source: Calculated from CBS, 2012

Three provinces namely 2, 6 and 7 fall below the national average in both cases. Overall scenarios show that gender discrepancy in ownership of fixed assets prevails throughout the country. This clearly indicates that women face varieties of barriers to accessing, owning and controlling fixed assets- house, land and other properties. The social and cultural barriers are still prevalent as a major challenge for women property right. And also right to property has guaranteed that women are free to take decision to acquire, own or sell their property; however, this does not always imply that they have ultimate control of these assets. As noted in by IOM (2016), the legal right of women to land and property may not yet be recognized socially legitimate. Likewise, the strong patriarchal value might be another significant barrier to women's right over land ownership. 


\section{Conclusion}

Ownership of fixed assets especially of house and land is a significant indicator of wealth, political power and social security in Nepal. It also decides the economic dependence or independence of a person and also restricted in pursuit of self-employment activity of his/her choice. There is wide gender discrepancy in ownership of house and land in the country. Female ownership over these assets is very low as compared to the male counterpart and the scenario of gender discrepancy varies across the ecological zones and provinces. The socio-cultural barriers are still a major challenge for women's property ownership in Nepal. Patriarchy and traditional conservative social set-up is one of the persistent barriers to women's ownership of fixed assets. For this, organized and effective education campaign and women-friendly legal provisions would be beneficial to reduce the gender gap on ownership of fixed assets.

\section{References}

Acharya, S. (2014).Gender, Jobs and Education: Prospects and Realities in Nepal, Kathmandu: UNESCO.

Agrawal, B. (1994). A field of one's own: Gender and land rights in South Asia. South Asian Studies 58, Cambridge University Press: New Delhi.

Antonopoulos, R \&Floro, M. S. (2005). Asset ownership along gender lines: Evidence from Thailand, Working papers, The Levy Economics Institute, No. 418 http:// hdl.handle.net/10419/31544

Asian Development Bank (ADB). (2016). Gender equality results case study: Nepal gender equality and development of women project. Mandaluyong City, Philippines: ADB

ADB. (2010). Overview of Gender Equality and Social Inclusion in Nepal, Manila: ADB

Basnet, L. D. (2013). Gender discrimination and children's right to education in Nepal: Perspectives of parents and children. Master's thesis, Norwegian University of Science and Technology Faculty of Social Sciences and Technology Management Norwegian Centre for Child Research, Trondheim, Norway.

CARE. (2015). Nepal: Gender relations in Nepal overview. Retrieved from emergencygender@careinternational.org

Central Bureau of Statistics (CBS) (2012).National Population and Housing Census 2011(National Report), Kathmandu: CBS 
The Third Pole: Journal of Geography, Volume 17, 2017

Cerise, S. \&Francavilla, F. (2012).Tackling the root causes of gender inequalities in the post-2015 development agenda, Paris: OECD Development Centre.

Doss, C.; Grown, C. \& Deere, C.D. (2008). Gender and asset ownership: A guide to collecting individual-level data, Policy Research Working Paper 4704, The World Bank, Poverty Reduction and Economic Management Network, Gender and Development Group.

FAO.(2011). Gender differences in assets, ESA Working Paper No. 11-12. Agricultural Development Economics Division, Food and Agriculture Organization of the United Nations, Retrieved from www.fao.org/economic/esa

Government of Nepal (GoN) \& UNDP (2014).Nepal human development report 2014: Beyond geography, Unlocking human potential, Kathmandu: GoN and UNDP

GoN). (2015). Economic Survey: Fiscal Year 2014/15. Kathmandu: Ministry of Finance.

International Organization for Migration (IOM).(2016). Barriers to women's land and property access and ownership in Nepal. Kathmandu: IOM.

Mahat, I. (2003). Women's development in Nepal: The myth of empowerment, The Fletcher Journal of International Development, XVIII: 67-72

Mishra, K. \& Sam, A. (2016). Does Women's Land Ownership Promote Their Empowerment? Empirical Evidence from Nepal, World Development, 78 (360-371), Retrieved from http://dx.doi.org/10.1016/j.worlddev.2015.10.003

Njuki, J. \& Mburu, S. (2013). Gender and ownership of livestock asset. In Njuki, J. \& Sanginga P. C. (Eds). Women, Livestock Ownership and Markets: Bridging the Gender Gap in Eastern and Southern Africa, New York and London: Routledge, pp 21-38

OHCHR and UN Women (2013).Realizing Women Rights to Land and Other Productive Resources, New York and Geneva: OHCHR and UN Women, Retrieved from www.ohchr.org/documents/publications/realizingwomensrightstoland.pdf

Pokharel, S. (2008). Gender discrimination: Women perspectives, Nepalese Journal of Development and Rural Studies, 5 (2): 80-87.

Shrestha, C.B., \&Rijal, S.P. (2016).Nepal: Cultural Geography. Kathmandu: Prakash Shrestha \& Sunil Shrestha

World Bank.(2008). Gender and asset ownership, World Bank Research Digest 7, 3(4). 